Viewpoints and Letters to the Editor are published in Hort- comments on matters of concern to horticulturists. These are Science to provide members of the American Society for Hor- not statements of official Society policy nor do they necessarticultural Science an opportunity to share their experiences and ily reflect the views of a majority of the Society's members.

\title{
Analysis of Flower Appreciation and Its International Comparison Contribute to Progress of Flower Production and International Flower Trade
}

\author{
Eisuke Matsuo \\ Faculty of Agriculture, Kagoshima University, Kagoshima 890, Japan
}

\begin{abstract}
What types of ornamental plants do people admire and how arc they appreciated in the world? It may be quite different from nation to nation or from culture to culture. For example, chrysanthemums, cherry blossoms, and pine trees are very popular in Japan, while roses and lawns are popular in Europe. Moreover, if we focus on a single species such as Easter lily (Matsuo, 1986b), a dwarf type is preferred in the United States; large, white flowers are more appreciated in European countries: and plants with a balance of leaves, stem, and flowers more admired in Japan. Such differences, which may depend on sociological or cultural background, affect commercial flower production, international flower trade, home gardening, plant breeding, and other horticultural pursuits. I here would like to introduce an outline of Japanese flower appreciation, including the types of plants that the Japanese people appreciate as "flowers", the way they appreciate them, the origin of this tradition, and the up-to-date changes to encourage further studies, comparisons, and discussions on this topic in the field of horticulture.
\end{abstract}

\section{Definition of "flower" in Japan}

What sorts of plants are referred to as flower in Japan? The word "flower" causes Japanese people to think not only of flower structures, but also of plants themselves. In reality, most authoritative Japanese dictionaries define flowers as any plant or plant part, including flowering organs, which are offered to the gods (Kamisama) or to ancestors at the household Buddhist altars or cemetery tombs. Thus, the Japanese definition of flower is not limited to the flowering organ, but includes all or parts of the plant. According to a survey I conducted, at $86 \%$ of the cemetery tombs checked, the offerings consisted

Received for publication 15 Dec. 1989. I acknowledge Toshiaki Ozasa, Hiroshima Univ., Hiroshima, and Joyce Latimer, Univ. of Georgia, Athens, for their reading this manuscript. The cost of publishing this paper was defrayed in part by the payment of page charges. Under postal regulations, this paper therefore must be hereby marked advertisement solely to indicate this fact. of green plants only (19\%) or a combination of green plants and flowering plants (67\%), as shown in Fig. 1 left (Matsuo, 1989).

In Japanese daily life, people sometimes collect flowers or plant materials such as vegetables, fruits, or garden or forest trees from the field, and then put them into cups or vases for decoration. Such behavior was more popular in the past than today, and is seen more often in rural than urban areas. Today, this is also observed in Japanese traditional flower arrangements; plant marerials, such as those mentioned above, were observed in $\approx 75 \%$ of 781 vases that were displayed in flower arrangement shows in Kagoshima in 1986-89 (my unpublished data).

The examples mentioned show clearly that, in Japanese culture, all plants are categorized as flowers if they are used for the improvement or decoration of their living environment. Such continuity, extension, or enlargement in Japanese thought is also observed in Shakkei, a Japanese gardening art form whereby the cultivated garden uses the surrounding landscape for completion, or in the use of wild, native plants or flowers such as chrysanthemum, rapeseed, cherry blossoms, or tea flowers for food, tea, or edible decorations in Japanese meals.

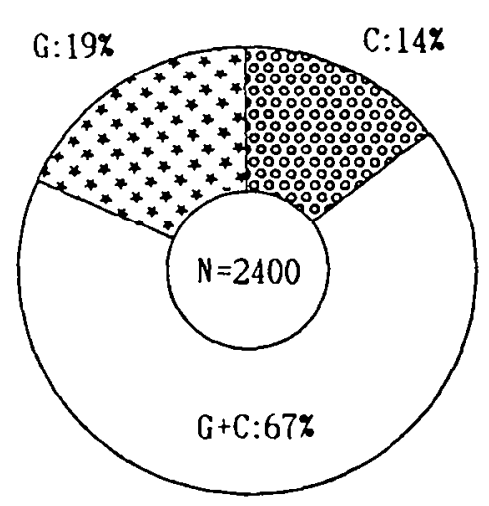

\section{Japanese concept of flower}

What concept do the Japanese people have of flower? In general, they think "beautiful", "cute", "heart-warming", "gentle", and so on (Hayashi et al., 1978; my unpublished data). These thoughts on flowers sound quite wan, calm, and simple, but not showy or gorgeous. In fact, according to a survey on the flower designs on Japanese lacquerwares, or shikki, rather simple plants such as Japanese plum, bamboo, or pine trees, are popularly used (Table 1) (my unpublished data). Moreover, as pointed out by historian Wakamori (1975), there is a tendency among Japanese to reject fascinating and gorgeous flowers introduced from Europe. Imanishi and Yonemori (1988a, 1988b) reported that many more Japanese people prefer wild-type flowers to improved, showy flowers. Toshimori (1983) and I (unpublished data) determined that fascinating and gorgeous flowers are listed as the flowers that some Japanese people do not like (Table 2).

When Japanese people look at gorgeous flowers such as a red rose, a red gladiolus, or a bird of paradise, they think "heavy", "unpleasant", "loud", "showy", "strong", or, sometimes, "ugly". However, this does not always mean that the Japanese do not

Fig. 1. Percentage of usage of green plants $(\mathrm{G})$; showy, colorful planfs $(\mathrm{C})$; or combinations of green and colorful plants $(G+C)$ seen on tombs (left, compiled after Matsuo. 1989) or used in arrangements (right, my unpublished data). 
Table 1. Plants seen in designs on Japanese lacquerwarc (Shikki). ${ }^{\mathrm{z}}$

\begin{tabular}{llcc}
\hline \hline Rank & Plants & No. & Percent \\
\hline 1 & Japanese plum & 23 & 26.4 \\
2 & Bamboo & 11 & 12.6 \\
3 & Chrysanthemum & 10 & 11.5 \\
4 & Maple tree & 9 & 10.3 \\
4 & Pine tree & 9 & 10.3 \\
\hline
\end{tabular}

${ }^{\mathrm{z}}$ Twenty plant species were observed on 87 pieces of Japanese lacquerware.

${ }^{y}$ Plants observed on $>10 \%$ of the wares are listed (my unpublished data).

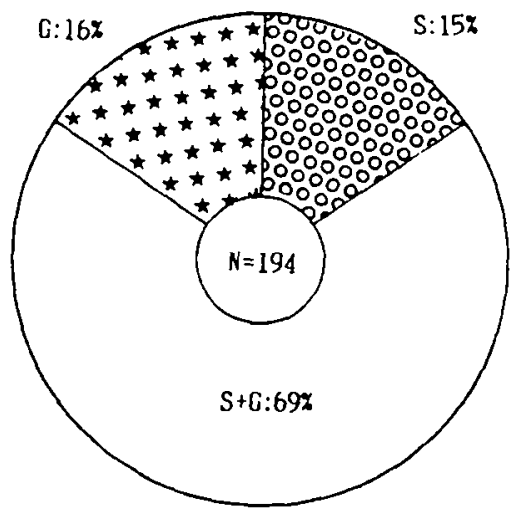

Fig. 2. Types of flowers Japanese like. I asked 194 respondents lo list three flowers they like. The types of three flowers liked were classified into three types: Gorgeous flowers only (G), simple and gorgeous flowers $(S+G)$, and simple flowers only (S) ( $m y$ unpublished data).

appreciate such showy flowers. For example, showy flowers such as rose, sweetpeas, freesia, etc., are listed as flowers they love, along with simple flowers such as lily of the valley, gypsophila, cherry tree, Cosmos bipinnatus, etc. (Toshimori, 1983; Imanishi and Yonezawa,1988b; my unpublished data).

Surveys (Asahi Shimbun, 1975; Nihon Keizai Shimbunsha, 1968, 1973, 1976, 1978a-c, 1980; Toshimori, 1983) of flowers displayed in homes or grown in private gardens reveal that the Japanese buy or would like to plant both simple plants such as Japanese plum, Rhodea japonica, Chlorophytum comosum, daffodil, Pecteilis radiata, Rhapis flabelliformis, or cherry trees, and showy ones, such as tulip, pansy, rose, or cattleya orchids. My survey on beloved flowers showed that $\approx 70 \%$ of the respondents listed both simple and showy flowers among the three most-beloved flowers (Fig. 2). Thus, it could be said that the Japanese love and want to grow not only the simple plants but also showy ones.

\section{Japanese appreciation of plants as flowers}

How do the Japanese appreciate these plants as flowers? It is well-known in Japan that leaves and branches, in addition IO flowers, are very important as a flower. This is expressed by a saying: "branches and leaves co-work with flower organs as a "flower",
Table 2. Flowers liked or disliked by Japanese students. ${ }^{\mathrm{z}}$

\begin{tabular}{clcc}
\hline \hline Rank & Name & No. & Percenl \\
\hline Liked flower & & \\
1 & Rose & 65 & 23.2 \\
2 & Cherry blossom & 58 & 20.7 \\
3 & Gypsophyila & 47 & 16.8 \\
4 & Cosmos & 41 & 14.6 \\
5 & Sunflower & 36 & 12.9 \\
6 & Carnation & 29 & 10.4 \\
& & & \\
Disliked flower & & \\
1 & Chrysanthemum & 18 & 8.8 \\
2 & Rose & 13 & 6.3 \\
3 & Sunflower & 9 & 4.4 \\
3 & Dahlia & 9 & 4.4 \\
5 & Camellia & 8 & 3.9 \\
\hline
\end{tabular}

Two-hundred-eighty respondents listed one IO three flowers they like; 130 flower types were listed and the flowers liked by $>10 \%$ of the respondents arc listed; 104 of 205 respondents listed no flowers they dislike, and 101 of them listed one IO three they dislike. Those who disliked any flowers listed 75 , and the flowers disliked by $>3.5 \%$ of the total respondents, arc listed (my unpublished data).

or "branches and leaves give life to the flower organs as a flower in the total aspect". This means that the flower itself does not always function as a flower, but a balance of flowers; leaves and branches are important as a flower. Such appreciation is typically observed with Easter lily or chrysanthemum. 'Hinomoto' Easter lily is preferred to 'Georgia' because the former has a good balance of flower, stem, and leaves, while the latter has leaves that are considered to be too long (Matsuo, 1986b). In chrysanthemum flower contests. when a pot chrysanthemum has unbalanced leaves, i.e., leaves that are too large or too small, or leaves that are dirty, diseased, broken, or insect-damaged, it is rated low. From the same point of view, flowers sold at the flower market are priced low when they have unbalanced leaves.

Such appreciation is extended into flower arrangement. In typical flower arrangements in Western countries, showy flowers are put into vases and the flower itself has an important role in decoration. In contrast to this, Japanese flower arrangements generally consist of green plants and showy, colorful flowers. Showy flowers are balanced with green plants, i.e., the green plants "give life to" (cooperate with) the showy flowers. Such combined use of green plants and showy plants is popular in flower arrangement, as well as with tomb flowers (Fig. 1).

With some flowers, however, the typical flower itself is appreciated as a "flower" mainly at full bloom, and the leaves are not as important as with others. Examples include sweetpeas, tulip, carnation, cattleya, dendrobium, and gladiolus (my unpublished data). It is interesting that most of these flowers were introduced from Western countries and became popular after the Meiji revolution. These showy flowers are, so to speak, the "monsters" of flower organs that catch our eye. In other words, people appreciate the beauty of flowers with their sight. In addition to sight, in Japan, aroma, touch, or hearing the whispering of branches or leaves plays an important role in how Japanese appreciate plants. In summary, the Japanese appreciate flowers with all their senses. Such appreciation is referred to by Japanese as being inspired by the motion of plants because the motion is analogous to the changes in people's surroundings (Wakamori, 1975).

There are other characteristics of flower appreciation in Japan. The Japanese notice and appreciate the effect of the environment on plant beauty. For example, morning dew enhances the beauty of plants differently than does the setting sun. In other words, Japanese see the environment reflected in their plants. Japanese appreciate not only flowers at full bloom, but also young plants and/or aged plants, as observed in bonsai. The appreciation that every stage of a plant has its own beauty to be admired was explained by Kenkou-houshi (Yoshida, 1331): cherry blossoms are tasteful not only at full bloom but also before the flowers open or after they have fallen. This type of appreciation is extended to a view of human life that is expressed by the saying "there is a fruit as well as a flower in our life".

Bonsai also shows that Japanese enjoy growing plants with their own hands and that they find themselves in these plants in a manner similar to the way they relate to their own children; i.e., they personify the plants they cultivate. At the same time, they enjoy the cut flowers or potted flowers they buy at flower shops. These are admired visually, because they have not been grown by their purchasers.

From the facts mentioned above, two types of flower appreciation can be categorized (Table 3). First, plants with showy, gorgeous flower organs are admired at full bloom. People observe the beauty of plants, which is concentrated in flower organs. with their own eyes. One typical example is buying and admiring cut flowers. This appreciation is quite acquisitive, thus I term it "acquiring" appreciation. Second, all plants, including plants with simple flowers, are admired with all senses. while people grow plants and integrate with them from emergence to death. In this sense, people treat and appreciate flowers as they do their children. This attitude toward flowers is very similar to fostering life (Matsuo, 1982, 1986a); thus, "fostering" appreciation. In Japan, both of these types of flower appreciation exist in one person, as shown in the list of beloved flowers (Table 2) and in Fig. 2. I call this phenomenon "dual structure of flower appreciation".

\section{Origin of the two types of flower appreciation}

How did this phenomenon come into existence? Judging from the plants listed in the oldest Japanese literature "Kojiki" and "Nihonshoki", written in the 8th century AD, plants were very important in people's daily life, both as materials for food, medicines, clothing, and dyes, and as materials to connect humans and the gods (Matsuda, 1977; Saito, 1977; Sakurai, 1977; Wakamori, 
Table 3. Two types of flower appreciation and their characteristics.

\begin{tabular}{|c|c|c|}
\hline \multirow[b]{2}{*}{ Itcms } & \multicolumn{2}{|c|}{ Types of appreciation } \\
\hline & Acquiring & Fostering \\
\hline Object & $\begin{array}{l}\text { Plants with beautiful } \\
\text { flower organs; } \\
\text { somerimes color- } \\
\text { ful fruits, stems, } \\
\text { or leaves }\end{array}$ & $\begin{array}{l}\text { All plants, even if they have } \\
\text { no beautiful flower organs; } \\
\text { usually plants with good } \\
\text { balance of flower organs, } \\
\text { leaves, and branches }\end{array}$ \\
\hline $\begin{array}{c}\text { Size and color } \\
\text { of flowers }\end{array}$ & $\begin{array}{l}\text { Large } \\
\text { Colorful } \\
\text { Dark-colored } \\
\text { Double }\end{array}$ & $\begin{array}{l}\text { Small } \\
\text { Even if only green } \\
\text { Light-colored } \\
\text { Single }\end{array}$ \\
\hline Concepl & $\begin{array}{l}\text { Showy } \\
\text { Gorgeous } \\
\text { Fair }\end{array}$ & $\begin{array}{l}\text { Simple } \\
\text { Cute } \\
\text { Familiar }\end{array}$ \\
\hline $\begin{array}{l}\text { Method of } \\
\text { admiration }\end{array}$ & $\begin{array}{l}\text { Appreciating them } \\
\text { at full bloom }\end{array}$ & $\begin{array}{l}\text { Growing and integrating } \\
\text { with them from emergence } \\
\text { to death }\end{array}$ \\
\hline Senses mainly used & Sight & All five senses \\
\hline
\end{tabular}

1975). This means that the ancient Japanese were familiar with growing plants and felt a closeness to them. It may be natural, therefore, that the agricultural Japanese have fostered appreciation of flowers.

Since then, many showy plants, such as Japanese plum, peach, lotus, chrysanthemum, tree-peony, irises, Daphne odora, clematis, tulip, sweetpea, carnation, cattleya, gladiolus, and dendrobium orchids, have been introduced into Japan, mainly from China in ancient days and from Europe in modem days. These plants were grown mainly by governing-class people (Matsuda, 1977; Nakao, 1984; Saito, 1977; Sakurai, 1977; Wakamori, 1975). Although the common people rejected these plants as a symbol of wealth, they also longed to obtain and grow them. In a similar manner, gatepoles, doors, and Shachihoko (a fish adorning the top of the gable, as a symbol of luck) were symbols of the governing class that became popular with common people who could have their own houses built.

During the 17th and 18th centuries, some of the plants, such as camellia, chrysanthemum. and azalea, which belonged to the governing class, became popular among the common people (Matsuda, 1977; Nakao, 1984), as did the addition of gatepoles, doors, and above-mentioned Shachihoko to their houses. Such was also the case with European flowers that were mainly introduced after the Meiji revolution (Nakao, 1984). These historical facts may have influenced the development of the acquiring appreciation of flowers.

Thus, the basically agricultural life of the Japanese people fostered appreciation of flowers, and their yearning for the plants used by the governing-class people brought forth and emphasized the acquiring appreciation of flowers. These historical facts resulted in the co-existence of both appreciation of fostering and acquiring, i.e., dual structure of flower appreciation in Japan. Moreover, the sense of balance seen in Japanese flower arrangements, the flowers dedicated at tombs or the household Buddhist altar, or in the selection of preferred cultivars, as discussed with respect to the Easter lily, may symbolize that the fostering and the acquiring appreciation co-exist in the same microcosm.

\section{Study of flower appreciation and its application to future horticulture}

The relative popularity of the two types of appreciation seems to be changing with time and location in Japan. For example, a teacher at a flower arrangement school indicated that younger pupils rather want to use showy plants and not simple ones. According to the owner of a flower shop, Younger people buy freesias without hesitatton, whereas elderly consumers do not buy them because of the lack of leaves (Matsuo, 1982). Imanishi and Yonezawa (1989) and Toshimori (1983) showed that the younger generation has different preferences and consciousness for flowers than the elder one. Imanishi and Yonezawa (1989) and Nippon Housou Kyoukai (1979) reported that the preference for flowers also differs from area to area in Japan.

Such changes and differences in Japanese flower appreciation should be clarified in detail by upcoming research surveys, which should be followed by the development of international comparisons of flower appreciation. This may belong to the study of ethnohorticulture, a part of socio-horticulture. These results will contribute to the analysis of cultural differences, resulting in progress in flower production and international flower trade.

\section{Literature Cited}

Asahi Shimbun Jigyo Kaihatsushitsu. 1975. Analysis and its data of horticultural market in Japan (In Japanese). Asahi Shimbunsha, To$\mathrm{m}$

Hayashi, Y., M. Eyama. T. Ozawa, M. Uchiyama, S. Takahashi, T. Hanai. M. Nagasawa, T. Kawahara, K. Kitazawa, M. Kishizuka, 1. Shinji, M. Kondo. T. Minomo, M. Aso, C.
Hamano. A. Kobayashi, K. Oba. S. Abe, and S. Suzuki. 1978. Studies on the psychological effects of flower, foliage and other green spaces in our environment (In Japanese with English summary). J. Agr. Sci. Tokyo Univ. Agr. Supl. 1:89-126.

Imanishi, H. and F. Yonezawa. 1988a. Relationship between flower and man (1) (In Japanese). Shinkaki 137:57-60.

Imanishi. H. and F. Yonezawa. 1988b. Relationship between fllower and man (2) (In Japanese). Shinkaki 139:62-66.

Imanishi. H. and F. Yonezawa. 1989. Relationship between flower and man (3) (In Japanese). Shinkaki 142:68-72.

Matsuda, O. 1977. Cultural history of flowers (In Japanese). Tokyo Shoseki, Tokyo.

Matsuo, E. 1982. Why horticulture is necessary in human life (In Japanese). Alps Insatsu, Kagoshima.

Marsuo, E. 1986a. On the education in farming (1). Agronomical education and agricultural education (In Japanese with English summary). Jpn. 1. Agr. Education 17(2):1-5.

Marsuo, E. 1986b. Easter lily production in the Netherlands and Japan (In Japanese). Shun-endo, Kagoshima.

Matsuo, E. 1989. Studies on the dedication of flowers at the tomb of ancestors: 1. Analysis of seasonal changes in cut flower dedicated at tombs in the Toso Cemetery, Kagoshima (In Japanese with English summary). Bul. Fac. Agr. Kagoshima Univ. 39:309-318.

Nakao, S. 1984. Floricultural history of east and west. The aesthetics of Japan (In Japanese). 1(3):18-30.

Nihonkeizai Shimbunsha Kikakuchousabu. 1968. Survey on the horticulture of the Nihonkeizai Shimbun readers (In Japanese). no. 2:1-88.

Nihonkeizai Shimbunsha Kikakuchousabu. 1973. Survey on the horticulture of the Nihonkeizai Shimbun readers (In Japanese). no. 13:1-22.

Nihonkeizai Shimbunsha Kikakuchousabu. 1976. Survey on the horticulture of the Nihonkeizai Shimbun readers (In Japanese). no. 19:1-33.

Nihonkeizai Shimbunsha Kikakuchousabu. 1978a. Survey on the horticulture of the Nihonkeizai Shimbun readers (In Japanese). no. 21:1-27.

Nihonkeizai Shimbunsha Kikakuchousabu. 1978b. Survey of the horticulture of the Nihonkeizai Shimbun readers (In Japanese). no. 22:1-35.

Nihonkeizai Shimbunsha Kikakuchousabu. 1978a. Survey of the horticulture of the Nihonkeizai Shimbun readers (In Japanese). no. 23:1-36.

Nihonkeizai Shimbunsha Kikakuchousabu. 1980. Survey of the horticulture of the Nihonkeizai Shimbun readers (In Japanese). no. 24:1-22

Nippon Housou Kyouki Housou Yoron Kenkyusho. 1979. Prefectural locality of Japanese peaple (In Japanese). Nippon Housou Kyoukai. Tokyo.

Sailo, S. 1977. Nature and beauty of Japan, 5. Flower-history of thought on flower (In Jap anese). Gyousei, Tokyo.

Sakurai. M. 1977. Ethnology of flowers (In Japanese). Yuzankaku, Tokyo.

Toshimori, S. 1983. Taste and conspicuous for flowers (In Japanese with English summary). Memo. Fac. Educ., Kagawa Univ. II. 33(1):3960

Wakamori, T. 1975. Flower and Japanese (In Japanese). Sougetsu Shuppan, Tokyo.

Yoshida. K. 1331. Cherry blossoms are not always tasteful only at full bloom (In Japanese). Tsurezuregusa 137. 